\title{
A respeito da questão da democracia no marxismo \\ (a polêmica entre Althusser e Poulantzas)
}

On the question of democracy in Marxism (the controversy between Althusser and Poulantzas)

A democracia, como bem observou Luciano Martorano (2011), de fato nunca gozou de tanto prestígio e influência como atualmente, particularmente desde as últimas décadas do século XX. Praticamente tornou-se um "consenso" o seu significado reproduzido pelos jornais e outras mídias controladas pelo grande capital, que restringem a democracia aos seus aspectos formais, e sobretudo a reduzem ao sufrágio universal, o que oblitera as formas alternativas de democracia. Como destaca Martorano, "a democracia tal como existe hoje seria não apenas o melhor regime político como também o único possível" (Martorano, 2011, p. 13).

Contudo, a questão da democracia no marxismo, e a sua crítica à democracia moderna (burguesa), não foi vilipendiada desde o seu nascedouro, nas obras de Marx. Pelo menos como Marx definiu a democracia: não enquanto uma forma de governo, como já faziam os gregos a partir de Herótodo, noção depois retomada pelos modernos. A problemática da democracia em Marx (e no marxismo) tem como tela a questão do Estado, particularmente as diferenças entre o Estado capitalista e o Estado no período de transição pós-revolução (ou no período socialista).

O marxismo (ou a ciência da história), com efeito, tem uma relevante contribuição à problemática do Estado, e à redefinição do significado dos conceitos de ditadura e de democracia, desde os clássicos como Marx,

\footnotetext{
É professor de Ciência Política da Universidade Federal do Rio de Janeiro (Rio de Janeiro, RJ, Brasil). E-mail: luizpmotta@ig.com.br.
} 
Lênin, Kautsky e Rosa Luxemburgo, até os mais recentes como Althusser e Poulantzas. Balibar (1975) tem razão quando afirma que a teoria de Marx não é um sistema, assentado num fundamento filosófico. Daí não estar acabada. Ademais, a exposição de sua teoria não tem um começo absoluto no seu conjunto, nem em cada uma das suas partes (por exemplo, na parte "econômica" que $O$ capital expõe).

No entanto, isso não significa que a teoria de Marx não seja sistemática no sentido científico, i.e., que não defina o seu objeto de estudo de forma a explicar-lhe a necessidade objetiva. O que confere à teoria de Marx o seu caráter sistemático, neste sentido, é a análise das diferentes formas da luta de classes e da conexão entre elas. Por isso, a problemática do Estado, e a da ditadura e da democracia, só pode ser definida a partir dos conflitos de classes que lhe dão o seu conteúdo, e demarcam as formas distintas de Estado. Bobbio tem razão quando afirma que Marx tem uma carga de originalidade por ser o primeiro escritor político que une uma concepção realista do Estado a uma teoria revolucionária da sociedade e do Estado (Bobbio, 1991, cf. p. 29).

A partir dos escritos de Marx, o pensamento marxista mobilizou uma intensa polêmica sobre a questão da democracia e da ditadura no tocante ao tipo de Estado em que se configurará o processo socialista em direção ao comunismo. A querela sobre a democracia e o Estado ganhou grande intensidade durante a II Internacional, ao mobilizar em torno dessa questão lideranças políticas e intelectuais como Lênin, Bernstein, Rosa Luxemburgo e Kautsky. Entretanto, essa discussão atravessou décadas. Nos anos 1970, foi travada uma ampla discussão sobre qual a estratégia - revolucionária ou reformista - para o socialismo. A questão retornou com vigor a partir da emergência do chamado "eurocomunismo, debate que mobilizou, além do intelectual socialista Bobbio (ligado ao Partido Socialista italiano), dirigentes políticos como Enrico Berlinguer, Santiago Carrillo, Pietro Ingrao e intelectuais como Rossana Rossanda, Christine Buci-Glucksmann, Valentino Gerratana, Giuseppe Vacca, Umberto Cerroni, Henri Weber, Étienne Balibar e principalmente Louis Althusser e Nicos Poulantzas. A maior parte dos intelectuais que participaram desse debate nos anos 1970 situava-se na França e na Itália, pois refletia as formações sociais que tinham as principais organizações de esquerda em atuação na Europa ocidental, como os partidos comunistas e socialistas francês e italiano, sem falar em outras organizações 
de esquerda que atuavam naquele contexto como a Autonomia Operária e o grupo Il Manifesto, da Itália, ou o PSU (Partido Socialista Unificado) e o grupo Socialismo ou Barbárie na França.

Neste artigo mostrarei a contribuição da corrente althusseriana ao debate sobre a problemática da democracia e a transição socialista a partir da demarcação que estabeleceram entre a defesa da ditadura do proletariado (Althusser e Balibar), ou do socialismo democrático (Poulantzas). O ponto de partida para a análise será o debate travado sobre a democracia marcado por alguns dos principais dirigentes da II Internacional (Lênin, Kautsky, Bernstein e Rosa Luxemburgo), e em seguida pelos representantes do então chamado "eurocomunismo"; por fim, tratarei da polêmica entre Althusser e Poulantzas em torno da questão da ditadura do proletariado e do socialismo democrático.

\section{A concepção da democracia da II Internacional aos "eurocomunistas"}

$\mathrm{O}$ debate a respeito da democracia, e do papel do Estado, e sobre qual a estratégia para a construção do socialismo - pela via reformista ou revolucionária -, marcou o cenário marxista na virada de século e durante as duas primeiras décadas do século XX. A contenda girou em torno das seguintes questões, não obstante elas se cruzassem: o socialismo poderia se constituir pelas reformas políticas, sociais e econômicas, ou pela via da revolução "explosiva", de rupturas? Esse tema marcou a polêmica entre Eduard Bernstein e Rosa Luxemburgo. A segunda questão diz respeito a se a democracia é um valor universal (o "método" democrático) em oposição à ditadura, ou se a ditadura do proletariado é uma forma de democracia popular, ou de democracia de massas. E se for, qual é o nível de participação daqueles que se opõem ao grupo dirigente? Essa questão envolveu diretamente Lênin e, na sua oposição à direita, Kautsky, e à sua esquerda Rosa Luxemburgo.

Bernstein, de fato, foi o primeiro intelectual do campo marxista a romper explicitamente com a perspectiva da ruptura e da revolução. Ao rejeitar a tese de Marx e Engels sobre o colapso do capitalismo expresso no Manifesto, Bernstein defende que única forma cabível seria a via parlamentar para a construção de um socialismo na base de reformas sociais. E o socialismo pela via "pacífica" pode ser realizado já que a democracia, para Bernstein, possui um valor universal, onde prepondera a decisão majoritária, e a defesa das minorias. A democracia no seu entender não está restrita a algumas classes, 
ou frações, mas sim difusa no conjunto das classes sociais, i.e., tem caráter universal. Essa posição de Bernstein fica nítida nesta passagem: "[Q]uanto mais for adotada e governar a consciência geral, tanto mais a democracia será igual, em significado, ao grau mais elevado possível de liberdade para todos" (Bernstein, 1997) p 113).

Sendo a democracia universal, atingindo todas as classes, torna-se a alternativa à revolução violenta, o que garante uma "transição da moderna ordem social para outra mais evoluída” (Bernstein, 1997, p.115). Ao contrário de ser herdeira do igualitarismo de Rousseau, ou dos socialistas pré-marxistas, o socialismo seria o "herdeiro legítimo" do liberalismo. O socialismo, segundo Bernstein, seria "o desenvolvimento e a garantia de uma livre personalidade" (Bernstein, 1997, p. 117). O fundamento do socialismo não se deve às questões materiais, ao controle e repartição da produção, e do poder político, mas sim da moral. É Kant quem Bernstein evoca como precursor do socialismo.

A crítica às teses de Bernstein veio à tona rapidamente por Rosa Luxemburgo em Reforma social ou revolução?, escrito em 1899, no qual ela refuta, passo a passo, os argumentos defendidos por Bernstein. Um dos principais aspectos de sua crítica a Bernstein diz respeito à capitulação deste pela concepção liberal, e legalista, da modernidade burguesa. Enquanto a revolução demarca um sentido de ruptura e descontinuidade, o legalismo liberal reproduz as relações de poder vigentes sob a aura do universalismo e dos direitos. Como afirma Rosa:

A revolução é o ato fundador da história de classes, a legislação é a continuidade do vegetamento político da sociedade. $O$ trabalho da reforma legal não tem, em si, uma força motriz própria, independentemente da revolução; em cada período histórico ele apenas se movimenta sobre a linha, e pelo tempo em que permanece o efeito do pontapé que lhe foi dado na última resolução ou, dito de maneira concreta, apenas no quadro da forma social que foi colocada no mundo pela última transformação. (...) Uma revolução social e uma reforma legal não são fatores diferentes por sua duração, mas pela sua essência (Luxemburgo, 2011, vol. 1, p. 68-69).

Rosa destaca a identificação das posições de Bernstein com o liberalismo, na medida em que ele abandona o conceito de classes sociais pelo emprego da categoria de indivíduos. Há uma clara desistência de Bernstein com relação ao conceito central do marxismo, que é o de luta de classes. Numa passagem Rosa demarca claramente essa posição liberal de Bernstein: 
Em uma sociedade de classes, porém, a luta é um fenômeno completamente natural, inevitável - Bernstein desmente, em última conseqüência, até mesmo a existência das classes em nossa sociedade: a classe trabalhadora é, para ele, apenas um amontoado de indivíduos fragmentados, não apenas do ponto de vista político e espiritual, mas também econômico (Luxemburgo, 2011, vol. 1, p. 78).

Passados mais de dez anos desse debate, que marcou a virada para o século XX, mais uma vez a polêmica sobre a ditadura do proletariado e o conceito de Estado é retomado, agora a partir da vitória da Revolução Russa de 1917. A tomada do poder pelos bolcheviques, e a implantação da ditadura do proletariado, acabou por concretizar a cisão entre os socialistas e comunistas, ou entre os reformistas e os revolucionários, iniciada a partir da Primeira Grande Guerra, em 1914.

O texto de Kautsky A ditadura do proletariado, de 1918, é uma dura crítica aos primeiros momentos da Revolução Russa, e retoma em grande medida as posições de Bernstein na defesa da democracia em oposição à ditadura, embora não associe o socialismo ao liberalismo como fez este último. Há para Kautsky uma intensa oposição ao que ele denomina de "método democrático" do "método ditatorial", além da avaliação positiva sobre a Comuna de Paris em relação à Revolução Russa. A posição central de Kautsky é a de que o socialismo é impensável sem a democracia. Assim como Bernstein, Kautsky tem a crença no sufrágio universal, o qual permitiu às "classes sociais mais baixas do povo tomar a palavra” (Kautsky e Lênin, 1979, p. 20). É a democracia que fornece o indicador mais seguro da maturidade do proletariado.

Essa posição de Kautsky foi incompatível com a de Lênin. E essa ruptura entre socialistas e comunistas abriu uma ferida que nunca foi cicatrizada até os dias de hoje. A demarcação de Lênin em relação à ruptura revolucionária e a constituição da ditadura do proletariado representaram a defesa das posições políticas do Marx maduro ${ }^{1}$. Lênin (1978), em O Estado e a revolução, escrito um pouco antes da vitoriosa revolução de outubro de 1917, retoma os argumentos políticos centrais de Marx e Engels sobre o papel do Estado. Além de surgir a partir das contradições de classe, o Estado é um órgão de dominação de classe e cabe a ele a função repressora sobre as classes subalternas. Daí a necessidade de substituir o Estado capitalista pelo Estado de

O termo "Marx maduro" é empregado por Lênin em O Estado e a revolução, na tradução portuguesa (Lênin, 1978, vol. 2, p. 237). 
transição, com o escopo de extingui-lo, e consequentemente a democracia, já que esta é uma forma de Estado.

Não há princípio universal de democracia no entender de Lênin apoiado nos textos de Marx e Engels, e isso o coloca num campo diametralmente oposto ao de Kautsky. Para o marxismo, a pergunta sobre a democracia seria "para que classe?", e tampouco a ditadura é um conceito geral, já que haveria distinções entre uma ditadura revolucionária em relação a uma ditadura reacionária, ou conservadora. A ditadura não é uma forma de governo, como também a democracia, já que há uma distinção para Lênin entre o que é a democracia burguesa e os seus limites em relação à democracia revolucionária na qual haja uma ampla participação dos setores subalternos a partir da formação de novas formas de práticas políticas. Como observa Lênin, "não é de modo algum a mesma coisa. Assim, também, é absolutamente falso que uma classe não possa governar; tal asneira só pode brotar de um 'cretinismo parlamentar', que nada vê fora do parlamento burguês e nada observa fora dos 'partidos dirigentes"' (Kaustky e Lênin, 1979, p. 104). A despeito da linguagem adjetivada de Lênin, de fato o seu olhar é mais agudo em relação ao de Kautsky, pois, além de perceber os limites da esfera parlamentar, há a sua defesa de novas formas de participação numa clara ruptura com a república moderna burguesa.

Embora Rosa Luxemburgo se posicione no campo da esquerda revolucionária, a sua crítica aos caminhos tomados pela Revolução Russa foi implacável, ainda que não tomasse uma posição de opositora a ela como fez Kautsky. A sua defesa da democracia ultrapassa os limites da democracia liberal burguesa por identificar o socialismo revolucionário como a verdadeira acepção de democracia.

Em seu texto A revolução russa, Rosa Luxemburgo de fato critica a dissolução da Assembleia Constituinte e a supressão da democracia em geral por Lênin e Trotsky, haja vista que, com o fim dos mecanismos mínimos de eleições, o que veio a se constituir foi o "socialismo por decreto". A ditadura do proletariado para Rosa, distintamente da dominação de classe burguesa que não requer a formação nem a educação política de toda a massa do povo, necessita da intensa mobilização e participação popular. Como afirma Rosa, é o seu elemento vital, o ar sem o qual não pode viver (Luxemburgo, 2011, vol. 2, p. 205).

A máxima extraída desse texto - "Liberdade somente para os partidários do governo, somente para os membros de um partido - por mais numerosos 
que sejam -, não é liberdade"2 - não pode ser confundida, ou distorcida, por uma tomada de posição liberal. A diferença em relação à democracia liberal moderna fica clara nessa passagem:

[S]e a vida pública dos Estados de liberdade limitada é tão medíocre, tão miserável, tão esquemática, tão infecunda, é justamente porque, excluindo a democracia, ela obstrui a fonte viva de toda a riqueza e de todo progresso intelectual. (...) É preciso que toda a massa popular participe. Senão o socialismo é decretado, outorgado por uma dúzia de intelectuais fechados num gabinete. (...) A prática do socialismo exige uma transformação completa no espírito das massas, degradadas por séculos em vez de instintos egoístas; iniciativa das massas em vez de inércia; idealismo, que faz superar todos os sofrimentos, etc. (Luxemburgo, 2011, vol. 2, p. 207-208).

A consequência dessa ausência de participação das massas é o fortalecimento do poder da burocracia partidária e estatal, formando uma ditadura burguesa de corte jacobino, e tornando-se um dique de contenção ao crescimento da vida pública (de participação política). O erro da posição de Lênin-Trotsky consiste precisamente em opor, tal como Kautsky, a ditadura à democracia. Enquanto Kautsky decide naturalmente pela democracia, i.e., pela democracia burguesa, Lênin-Trotsky se decidem pela ditadura em oposição à democracia e, assim, pela ditadura de um punhado de pessoas, i.e., pela ditadura burguesa. Segundo Rosa, são dois polos opostos, ambos igualmente muito afastados da verdadeira política socialista. Para ela, a ditadura do proletariado é o desenvolvimento máximo da democracia, sem parâmetros com a democracia moderna burguesa. Como ela afirma:

[O proletariado] tem o dever e a obrigação de tomar imediatamente medidas socialistas da maneira mais enérgica, mais inexorável, mais dura, por conseguinte, exercer a ditadura, mas a ditadura da classe, não de um partido ou de uma clique; ditadura da classe, isso significa que ela se exerce no mais amplo espaço público, com a participação sem entraves, a mais ativa possível, das massas populares, numa democracia sem limites. (...) Nunca fomos idólatras da democracia formal só pode significar que sempre fizemos distinção entre núcleo social e a forma política da democracia burguesa; que sempre

\footnotetext{
O trecho continua: "Liberdade é sempre a liberdade de quem pensa de modo diferente. Não por fanatismo pela 'justiçaa', mas porque tudo quanto há de vivificante, salutar, purificador na liberdade política depende desse caráter essencial e deixa de ser eficaz quando a 'liberdade' se torna privilégio" (Luxemburgo, 2011, vol. 2, p. 205-206).
} 
desvendamos o áspero núcleo da desigualdade e da servidão sociais escondido sob o doce invólucro da igualdade e da liberdade formais - não para rejeitá-las, mas para incitar a classe trabalhadora a não se contentar com o invólucro, incitá-la a conquistar o poder político para preenchê-lo com um conteúdo social novo. A tarefa histórica do proletariado, quando toma o poder, consiste em instaurar a democracia socialista no lugar da democracia burguesa, e não suprimir toda democracia. (...) A democracia socialista começa com a destruição da dominação de classe e a construção do socialismo. Ela começa no momento da conquista do poder pelo partido socialista. Ela nada mais é que a ditadura do proletariado. (...) Mas tal ditadura precisa ser obra de classe, não de uma pequena minoria que dirige em nome da classe; quer dizer, ele deve, a cada passo, resultar da participação ativa das massas, ser imediatamente influenciado por elas, ser submetida ao controle público no seu conjunto, emanar da formação política crescente das massas populares (Luxemburgo, 2011, vol. 2, p. 209-210).

O tema da ditadura do proletariado, ou da via democrática do socialismo, de fato retornou com intensa força em meados dos anos 1970 na Europa, sobretudo na Itália e na França, com a participação de intelectuais vinculados aos partidos comunistas e socialistas, e das pequenas agremiações revolucionárias. Participaram desse debate Norberto Bobbio, Pietro Ingrao, Santiago Carrillo, Enrico Berlinguer, Valentino Gerratana, Rossana Rossanda, Christine Buci-Glucksmann, Luciano Gruppi, Lucio Lombardo Radice, Bernard Edelman, Giacomo Marramao, David Kaisergruber, Claude Lefort, Cornelius Castoriadis, entre outros. No entanto, o destaque maior foi o debate interno no marxismo althusseriano entre os defensores da ditadura do proletariado, Althusser e Balibar, e o mais consistente defensor do socialismo democrático, Nicos Poulantzas.

Esse debate, que ultrapassou as fronteiras da Europa ${ }^{3}$, foi principalmente motivado, a partir do sucesso eleitoral do Partido Comunista Italiano, por sua defesa do socialismo pela via democrática parlamentar, cuja posição influenciou os demais partidos comunistas europeus, particularmente o francês e o espanhol, e por sua autonomia diante das posições políticas da URSS.

No Brasil foi marcante, no final dos anos 1970 e início dos anos 1980, o debate sobre se a democracia teria ou não um valor universal, e se ainda seria válido o conceito de ditadura do proletariado e a via revolucionária. O ponto de partida foi o artigo de Carlos Nelson Coutinho (à época, vinculado ao PCB) "A democracia como valor universal", publicado na revista Encontros com a Civilização Brasileira n 9, no ano de 1979. Participaram desse debate Luiz Werneck Vianna, Marilena Chaui, Marco Aurélio Nogueira, Francisco Weffort, Adelmo Genro Filho, Leandro Konder, Pedro Celso Uchoa Cavalcanti, Theotônio dos Santos, João Machado, Eder Sader, Ozeas Duarte, Décio Saes. 
Esse fenômeno foi denominado de "eurocomunista". "Eurocomunismo", com efeito, é um termo vago que abrange diferentes posições dos partidos comunistas ${ }^{4}$ europeus, e uma associação ao socialismo democrático, embora a concepção de socialismo democrático estivesse presente em outros partidos, como os socialistas da Itália e da França (este com uma forte corrente de caráter autogestionário que representava sua ala esquerda).

Como observa Bob Jessop, há duas tendências no eurocomunismo, uma de direita e outra de esquerda. A tendência mais à direita tende a ver a transição democrática ao socialismo como gradual a progressiva, baseada numa aliança de classes antimonopolista sob a liderança do Partido Comunista, sem transformação dos aparatos de Estado, haja vista que os concebem enquanto instituições neutras, no fortalecimento do parlamento no controle sobre o Estado e a economia, e na incorporação dos sindicatos na formulação do planejamento econômico. Em suma, vê o socialismo democrático como uma longa e vagarosa marcha por meio das instituições da sociedade política e civil. Já a posição de esquerda do eurocomunismo tende a ver a transição como uma longa série de rupturas, com base nacional-popular, numa ampla aliança que envolva tanto os novos movimentos sociais como uma união de classes organizada de modo plural. Além disso, compromete-se profundamente com as transformações dos aparatos estatais como parte do processo democrático e a reestruturação do Estado e da economia a partir de uma democracia de base, da autogestão e da unificação de um fórum parlamentar (Jessop, 1985, p. 297-298).

Essa posição da tendência mais reformista fica clara nessta passagem do artigo de Berlinguer sobre sua crença das instituições democráticas: "A primeira necessidade baseia-se em assegurar o correto e normal funcionamento das instituições democráticas e em garantir um clima cívico na luta política” (Berlinguer, 1977, p. 69). Numa entrevista em 1976, Berlinguer defende a presença da empresa privada e reproduz a concepção de cidadania nos moldes liberais:

Consideramos necessárias várias formas de gestão econômica, reconhecendo amplo espaço à empresa privada dentro de uma programação pública nacional, elaborada $\mathrm{e}$ realizada democraticamente. Quanto às tentações autoritárias, o modo mais seguro de

A diferença era nítida no campo internacional entre os partidos comunistas italiano e francês, pois enquanto o primeiro advogava uma independência total da URSS, além de uma posição crítica como no caso da Polônia, o PCF esteve alinhado à URSS e deu apoio ao golpe de estado na Polônia em 1981. 
evitá-las é dar ao poder político a mais ampla base de consenso e de participação dos cidadãos, realizar uma aliança entre todos os partidos populares a antifascistas, e manter viva e desenvolver a adesão dos cidadãos às liberdades (Berlinguer, 2009, p. 107).

O livro de Santiago Carrillo "Eurocomunismo" e Estado, de 1977, é certamente a exposição mais sistemática do eurocomunismo na sua vertente mais reformista. Nesse livro, Carrillo traça as principais posições do chamado "eurocomunismo" perante a democracia e a ditadura do proletariado. Sua posição é clara na defesa da democracia como valor universal e do Estado democrático expressando os anseios do "povo", e não mais das classes sociais, o que confere ao Estado uma acepção próxima das perspectivas institucionalistas:

Um Estado democrático deve caracterizar-se pela descentralização, de forma que a administração opere com mais flexibilidade, mais perto e mais de acordo com a vontade dos governados. Um tipo de Estado deste gênero poderá ser transformado com maior facilidade num Estado apto a chegar ao socialismo por uma via democrática; num Estado mais facilmente controlado pelos eleitos do povo; e, por conseguinte, num Estado mais protegido frente às contingências de um golpe de força. (...) Essa concepção do Estado e da luta pela sua democratização pressupõe a renúncia, em sua forma clássica, à ideia de um Estado operário camponês (Carrillo, 1978, p. 67).

O contraponto a essa perspectiva mais branda está nas posições de Pietro Ingrao, que representava a ala esquerda do "eurocomunismo". Sua posição difere da dos demais na medida em que propõe que as ações das massas num sistema democrático visam à reinvenção das instituições, e não apenas à manutenção destas:

Diria que, quanto mais amplos forem os direitos de liberdade política, tanto mais rigorosa deverá ser a luta para golpear as bases econômicas da velha ordem, e a luta - eis um ponto decisivo - para renovar e desenvolver as instituições democráticas, para vinculá-las às massas, para animá-las e torná-las eficazes contra a resistência

"O leitor talvez estranhe a freqüência com que nas linhas que se seguem utilizo o termo'eurocomunismo'. É que ele está bastante em moda e, ainda que não tenha sido cunhado pelos comunistas e que seu valor científico seja duvidoso, já reveste um significado perante a opinião pública e, em termos gerais, diferencia uma das tendências comunistas atuais. (...) Porém a política e as implicações teóricas que justificam o'eurocomunismo' definem uma tendência do movimento progressista e revolucionário moderno que trata de cingir-se às realidades do nosso continente - conquanto seja válida em essência para todos os países capitalistas desenvolvidos - e de adaptar a elas o desenvolvimento do processo revolucionário mundial, característico de nossa época" (Carrillo, 1978, p. 2). 
das forças do passado. (...) [A] experiência vivida nos países de capitalismo maduro mostra-nos que a expansão da democracia em todos os níveis é hoje uma condição para enfrentar os novos modos de penetração e dominação do capital monopolista para romper seu sistema de alianças e encaminhar a construção de um novo bloco de poder; nisso é que reside o nexo profundo, para nós, entre luta democrática e luta socialista (Ingrao, 1980, p. 112, grifos do original).

\section{Althusser e a defesa do conceito de ditadura do proletariado e a estratégia do socialismo democrático de Poulantzas}

Althusser embora tenha tido sempre (pelo menos desde os anos 1960) uma posição rebelde dentro do Partido Comunista Francês - a exemplo de seu apoio explícito ao maoísmo e à Revolução Cultural chinesa -, não tinha até então escrito nenhum ataque direto ao Comitê Central (CC) no que tange às posições do PCF no plano político interno, tampouco em relação à URSS. Entretanto, com a adesão do CC à estratégia eurocomunista, Althusser (juntamente com Balibar $)^{6}$ se insurgiu contra essa posição reformista adotada pelo PCF a partir de seu XXII Congresso, de cujo programa foi excluído o conceito de ditadura do proletariado, e no qual a democracia como um valor universal tornou-se a palavra de ordem central. Althusser, ao criticar essa posição reformista do PCF, defendeu, de um lado, o valor científico no marxismo do conceito de ditadura do proletariado, e, do outro, a experiência chinesa da Revolução Cultural como modelo de transição socialista ao comunismo devido à intensa crítica à burocratização do partido revolucionário ${ }^{7}$.

A posição do PCF em relação ao abandono do conceito de ditadura do proletariado deve-se, para Althusser, por um lado, à renúncia da análise concreta das relações de classe, e, por outro, à influência da ideologia burguesa sobre o partido, sobre sua concepção da teoria e sobre sua própria prática política (Althusser, 1978, p. 28). Nesse aspecto, Althusser segue de perto a posição maoísta, pois entende que o próprio partido revolucionário não está impermeável às contradições, e tampouco à ideologia burguesa que acaba por influenciar setores representantes de posições de direita do partido. Sua posição em relação a essa questão é completamente antagônica às posições stalinistas, que recusam aceitar a existência da contradição no interior do

Somam-se a eles outros intelectuais vinculados ao PCF como Jean Pierre Lefebvre, Georges Labica, Guy Bois e Maurice Moissonier (Althusser, 1978, p. 110).

Uma posição convergente a minha afirmativa encontra-se em Andrea Cavazzini (cf. 2009, p. 80). 
partido. A despeito de Althusser concordar que inexista uma teoria do Estado marxista (pelo menos de modo sistemático), essa teoria está curso porque há como base tanto as observações e análises dos clássicos (Marx, Engels, Lênin e Mao) como também as experiências socialistas em diferentes formações sociais (Althusser, 1998, p. 276) ${ }^{8}$.

Essa oposição de Althusser ao PCF e a sua defesa do conceito de ditadura do proletariado encontram-se no contexto da sua obra que se classifica como "textos sobre a crise do marxismo", nos quais se incluem: $22^{\circ}$ Congresso; $O$ que não pode haver no partido comunista; "O marxismo como teoria finita"; "Enfim, a crise do marxismo"; "O marxismo hoje"; e o inédito "Marx dentro dos seus limites”; todos textos escritos entre os anos 1977 e 1978. Já Balibar expõe a sua posição no livro Sobre a ditadura do proletariado, de 1976.

Althusser, com efeito, demarca claramente em sua intervenção no XXII Congresso do PCF que, embora os países do Terceiro Mundo estivessem num contexto favorável, a exemplo da descolonização dos países africanos como Angola, Moçambique, Guiné Bissau e Cabo Verde, da vitória vietnamita sobre os EUA, da vitória do Khmer Vermelho no Camboja (antes da denúncia dos genocídios), e das lutas políticas e sociais na América Latina, o socialismo do Leste Europeu estava vivendo uma crise. A crise do chamado "socialismo real" no Leste Europeu demonstrava claro sinal de esgotamento do stalinismo, fosse no plano político como também no teórico.

Althusser observa que o abandono da ditadura do proletariado é por si mesmo um ato simbólico ao apresentar de modo espetacular a ruptura com o passado, abrindo a frente de um "socialismo democrático", distinto do modelo soviético e do Leste Europeu. Althusser aponta que a dominação burguesa na França não se restringe ao aspecto político e parlamentar, mas vai além ao incluir tanto a dominação econômica como também a ideológica. A ditadura do proletariado e de seus aliados é a resposta marxista a esse sistema de dominação. Para Althusser:

A forma política desta ditadura ou dominação de classe do proletariado é a "democracia social" (Marx), a "democracia de massa", a "democracia até o fim” (Lênin). Mas, enquanto dominação de classe, esta dominação não se reduz unicamente à suas formas políticas: é simultaneamente dominação de classe na produção e na ideologia (Althusser, 1978, p. 39-40).

Essa observação consta no texto "Enfim, a crise do marxismo". 
Também a revolução não tem uma forma de ação a priori, o que significa afirmar que a via da violência revolucionária não está descartada:

É a relação de forças que determina as formas de ação revolucionárias possíveis e necessárias. Quando a burguesia está politicamente em estado de empregar a violência, quando a emprega, então as massas só podem responder com violência revolucionária. Mas se, após uma longa luta de classes e pesados sacrifícios, a relação de forças se encontra, aqui ou ali, altamente favorável ao proletariado e aos trabalhadores unidos e altamente desfavorável ao imperialismo mundial e à burguesia nacional, então a passagem pacífica e até a democrática não só se torna possível como se impõe (Althusser, 1978, p. 41).

Como Althusser deixa bem claro, a ditadura do proletariado não é um conceito isolado que possa ser "abandonado" ao seu destino solitário, pois está relacionado ao conjunto de conceitos forjados por Marx a partir de 1845. A "quebra" dos aparatos estatais ocupa um lugar central no entender de Althusser a respeito das práticas políticas emergentes durante o período de transição. Segundo Althusser:

Destruir o Estado burguês, para o substituir pelo Estado da classe operária e dos seus aliados, não é juntar o adjetivo 'democrático' a todos os aparelhos de Estado existentes, é mais do que uma operação formal e potencialmente reformista, é revolucionar na sua estrutura, na sua prática e ideologia os aparelhos de Estado existentes, suprimir alguns, criar outros, é transformar a formas da divisão do trabalho entre os aparelhos repressivos, políticos e ideológicos, é revolucionar os seus métodos de trabalho e a ideologia burguesa que domina as suas práticas, é assegurar-lhe novas relações com as massas a partir das iniciativas das massas, na base de uma nova ideologia proletária a fim de preparar o 'enfraquecimento do Estado', isto é, a sua substituição pelas organizações de massas (Althusser, 1978, p. 51-52).

A posição de Althusser é clara: o socialismo é constituído a partir de uma ruptura radical com a política e o Estado modernos. Novas práticas políticas e ideológicas se constituem nesse momento de transição ao comunismo, e o papel das massas é fundamental para que impeçam a manutenção das velhas práticas políticas e ideológicas burguesas, a exemplo da burocracia e da ideologia do burocratismo que tanto assolaram os partidos revolucionários e os Estados de transição. 
Em “Marx dentro dos seus limites”, Althusser reitera a importância do conceito de ditadura do proletariado na teoria e na política marxista. No aspecto teórico evidencia a ruptura com o jovem Marx haja vista que a partir do 18 Brumário o Estado significa um aparelho, uma máquina, e não uma questão relacionada à alienação. O Estado é separado, o que significa dizer que o Estado não é idêntico à política, nem à vida genérica da espécie humana. O Estado é separado porque, como afirmava Marx, é um instrumento do qual a classe dominante se serve para perpetuar sua dominação de classe. Por isso que é estratégico que a classe operária tenha de conquistar o Estado, pois, como observa Althusser, "não que o Estado seja universal em ato ou no todo, não que o Estado seja 'determinante em última instância', mas porque é o instrumento, a 'máquina', ou o 'aparelho', do qual tudo depende quando se trata de mudar as bases econômico-sociais da sociedade, isso quer dizer, das relações de produção" (Althusser, 1994, p. 436).

Embora o Estado seja separado, não significa que ele seja autônomo. Não obstante haja uma pluralidade de aparelhos (ideológicos, repressivos, políticos), todos eles têm a mesma finalidade: a manutenção do poder da classe dominante. Os aparelhos, por mais que sejam diversos e separados entre eles, são adaptados ao seu objetivo enquanto fazem parte de um todo articulado que é o Estado. E o Estado torna-se então "esse aparelho, essa máquina, que serve de instrumento à dominação de classe, e à sua perpetuação" (Althusser, 1994, p. 458). Essa separação do Estado recebe, então, um novo sentido. O Estado é "separado" porque o seu corpo é moldado para produzir uma transformação de energia. É um corpo "especial” tal qual um "metal especial" cuja natureza especial é constituída por agentes de Estado, militares, policiais, agentes da justiça, agentes de diversas administrações. O Estado, como define Althusser, é uma máquina produtora de um tipo de energia específica que é a do poder legal, uma máquina que produz força (violência) calcada na lei (cf. Althusser, 1994, p. 477-478).

Além disso, Althusser ressalta que o conceito de ditadura do proletariado não pode ser confundido com um regime político, como Lênin já dizia em sua polêmica com Kautsky, haja vista que todo Estado é uma das formas da dominação de classe. De acordo com Althusser:

A dominação de classe abrange o conjunto das formas econômicas, políticas e ideológicas de dominação, o que isso quer dizer da exploração e da opressão de classe. Nesse conjunto, as formas políticas ocupam um setor mais ou menos extenso, mas 
sempre subordinado ao conjunto das formas. E o Estado torna-se então esse aparelho, essa máquina, que serve de instrumento à dominação de classe, e à sua perpetuação (Althusser, 1994, p. 458).

O conceito de ditadura no marxismo, portanto, não pode ser restrito, ou reduzido, a uma forma de regime político, já que há uma variedade de formas de dominação que ultrapassam a política e o Estado. Isso significa dizer, como ressalta Althusser em nítida concordância com Marx e Lênin, que a ditadura do proletariado tem como objetivo a forma mais larga de democracia, ou, em outras palavras, a forma política da ditadura do proletariado torna-se a mais ampla forma de democracia. Essa última expressão coloca a forma política no seu lugar, já que não reduz todas as formas de dominação somente à forma política. E, além disso, não se reduz a forma de dominação política exclusivamente à violência nua e crua típica de uma ditadura segundo a definição desta enquanto um regime político (cf. Althusser, 1994, p. 461).

Apesar dessa separação do Estado, isso não significa que ele tenha uma relação estanque com a sociedade. Longe disso, Althusser tece uma severa crítica tanto a Hegel como a Gramsci pela diferenciação da sociedade política e da sociedade civil, porque o Estado sempre penetrou profundamente a sociedade civil, não só por meio do dinheiro e do direito, não só por meio da presença e intervenção dos seus aparelhos repressivos, mas também por meio de seus aparelhos ideológicos. Para Althusser, o Estado sempre foi "ampliado", não sendo um fenômeno recente, ou restrito aos países de "democracia avançada”. Contudo, como ele afirma, as formas dessa ampliação mudaram no decorrer do tempo, desde a monarquia absoluta até o Estado do capitalismo imperialista (cf. Althusser, 1998, p. 287-288).

Nessa conjuntura do final dos anos 1970, em meio à emergência da crise do socialismo do Leste Europeu e do avanço do programa reformista do eurocomunismo, Althusser demarca claramente a sua posição de ruptura com essas duas perspectivas no campo da esquerda ao reivindicar a influência dos princípios da Revolução Cultural chinesa ${ }^{9}$ ao estabelecer a separação do partido revolucionário do aparato estatal. Essa sua posição converge com a

Como observa Fabrizio Carlino sobre a posição de Althusser em relação à crítica deste às posições eurocomunistas do PCF em 1976"A Revolução Cultural vem saudada com entusiasmo por Althusser, precisamente porque prevê a formação de organizações que agem externamente e sobre a superestrutura; na verdade, não basta mudar as relações de produção mas é necessário revolucionar também as ideologias enquanto os aparelhos ideológicos, que sempre são aparelhos de Estado, têm a sua eficácia especifica" (Carlino, 2010, p. 104). 
esquerda revolucionária italiana aglutinada no grupo do Manifesto, tendo à frente como uma de suas principais lideranças Rossana Rossanda. A convite de Rossanda, Althusser escreveu o texto "O marxismo como teoria finita”, em 1978, o qual desencadeou um intenso debate entre os intelectuais italianos e franceses e gerou diversas críticas pelos defensores do socialismo por via pacífica, como também os que questionaram Althusser quando este afirmou a inexistência de uma teoria do Estado marxista. Todavia, o fio condutor principal desse artigo é a crítica de Althusser à fusão do Estado com o partido revolucionário, que se tornou o dique de contenção para os avanços das transformações durante o período de transição socialista, ou da ditadura do proletariado, problemática essa já observada por ele no texto anterior "Enfim, a crise do marxismo" (cf. Althusser, 1998, p. 277-278). Althusser demarca bem essa questão quando afirma que:

por princípio, coerentemente com a sua razão de ser política e histórica, o partido deve estar fora do Estado, não só do Estado burguês, mas com mais razão ainda, do Estado proletário. O partido deve ser o instrumento número um da "destruição" do Estado burguês, antes de se tornar, prefigurando-o, um dos instrumentos do desaparecimento do Estado. A exterioridade política do partido em relação ao Estado é um princípio fundamental que se pode encontrar nos raros textos de Marx e de Lenin sobre essa questão. (Arrancar o partido do Estado para entregá-lo às massas: essa foi a desesperada tentativa de Mao na revolução cultural). Sem essa autonomia do partido (e não da política) em relação ao Estado, não se sairá jamais do Estado burguês, por mais que ele seja "reformado" (Althusser, 1998, p. 290, grifos do original).

Althusser defende a posição maoísta de que o partido revolucionário não poderia ser como os demais, i.e., um apêndice do aparelho político-ideológico do Estado típico das repúblicas modernas, limitado somente à representação e ao procedimento parlamentar. O partido revolucionário tem de permanecer fora do Estado por meio de sua atividade entre as massas, para impulsioná-las à ação de destruição-transformação dos aparatos do Estado capitalista e da extinção do novo Estado revolucionário. Para Althusser, o nó górdio da questão é o próprio Estado: seja sob a forma política da colaboração de classe ou da gestão da "legalidade" existente, seja o partido "se transformando no Estado"; e o dique de contenção a essa burocratização do partido-Estado está no seio do movimento de massas. 
Uma posição a se destacar em Althusser é a oposição dele ao idealismo presente em Marx, e largamente difundido pelos defensores da "ontonegatividade", sobretudo pelos de corte lukasciano, que rejeitam a existência da política e da ideologia no comunismo no chamado "reino da liberdade". De acordo com Althusser em "Marxismo como teoria finita":

Admito que o comunismo seja o advento do indivíduo finalmente libertado da carga ideológica e ética que faz dele 'uma pessoa'. Mas não estou tão seguro de que Marx entendesse assim essa questão, como o atesta a constante vinculação que ele estabelece entre o livre desenvolvimento do indivíduo e a 'transparência' das relações sociais finalmente livres da opacidade do fetichismo. Não é por acaso que o comunismo aparece como o contrário do fetichismo, o contrário de todas as formas reais nas quais aparece o fetichismo: na figura do comunismo como o inverso do fetichismo, o que aparece é a livre atividade do indivíduo, o fim da sua 'alienação', de todas as formas da sua alienação: o fim do Estado, o fim da ideologia, o fim da própria política. No limite, uma sociedade de indivíduos sem relações sociais (Althusser, 1998, p. 291, grifos do original).

Essa concepção idealista do comunismo obscurece mais do que esclarece o fato de que as relações de produção ainda permanecem na sociedade comunista e, consequentemente, as suas relações sociais e as suas relações ideológicas. A não existência do Estado não significa o fim da política. A política, com efeito, não seria mais a mesma que emergiu na modernidade burguesa, mas essa política seria substituída por uma política diferente, uma política em que o Estado inexiste, lembrando que mesmo na sociedade capitalista o Estado e a política não se confundem, ou seja, não são a mesma coisa ${ }^{10}$.

Numa posição completamente adversa à permanência de traços idealistas em Marx e no marxismo, e numa tomada de posição pelo materialismo, Althusser afirma que:

A experiência demonstra que a representação do comunismo que os homens - e especialmente os comunistas - fazem, por mais vaga que seja, não é estranha ao seu modo de conceber a sociedade atual e as suas lutas imediatas e futuras. A imagem do

10 "Em 1847, Marx e Engels explicam que o fim do Estado (a sua extinção) implica o fim da política. Logicamente, se (como o demonstra a Comuna) o fim do Estado começa imediatamente, e se este 'fim' não é uma diferença de grau, mas a combinação contraditória de duas tendências em luta, então o 'fim da política' deve também 'começar'imediatamente. No entanto, a tendência real que se esboçava já na Comuna, é totalmente diferente: é a constituição, de início hesitante e frágil, duma outra forma de 'política"' (Balibar, 1975, vol.1: p. 154). 
comunismo não é inocente: ela pode nutrir ilusões messiânicas que garantiriam as formas e o futuro das ações presentes, desviá-las do materialismo prático da "análise concreta da situação concreta", alimentar a ideia vazia de "universalidade" - que se encontra em algumas expressões equívocas similares, como o "momento geral", no qual uma certa "comunidade" de interesses gerais será satisfeita, como se fora a antecipação daquela que poderá ser um dia a universalidade do "pacto social" em uma "sociedade regulada". Esta imagem alimenta, enfim, a vida (ou a sobrevivência) de conceitos dúbios, com os quais, sob o modelo imediato da religião, da qual não forneceu nenhuma teoria, Marx pensou o fetichismo e a alienação, conceitos que, depois de 1844, retornarão com força nos Grundrisse e deixarão ainda os seus vestígios no Capital. Para decifrar o enigma é necessário retornar à imagem que Marx fazia do comunismo e submeter esta imagem problemática a uma crítica materialista. É através desta crítica que se pode perceber o que ainda resta em Marx de uma inspiração idealista do Sentido da história. Teórica e politicamente, vale a pena fazê-lo (Althusser, 1998, p. 292).

Se o marxismo é a teoria das distintas práticas articuladas (ideológicas, políticas, econômicas, teóricas), é certo que não desapareceriam num momento comunista, mas sim que teriam outra qualidade, outro conteúdo, se entendermos que os processos são constituídos por rupturas e não por continuidades.

Balibar converge em todos os aspectos da crítica tecida por Althusser ao grupo de Georges Marchais do PCF no tocante à identificação do conceito de ditadura do proletariado a uma forma de Estado, ou a um regime político. Em seu opúsculo Sobre a ditadura do proletariado, além de endossar os argumentos de Althusser sobre o caráter teórico do conceito de ditadura do proletariado, Balibar ratifica que o socialismo não é algo distinto da ditadura do proletariado, mas sim a própria ditadura do proletariado.

Balibar também demarca a diferença entre a teoria marxista do Estado e a ideologia jurídica burguesa quando afirma que toda democracia é uma ditadura de classe, seja de uma minoria (da burguesia), seja de uma maioria (do proletariado). Estado de direito é uma noção falsa, já que não há Estado sem lei, sem direito organizado, incluindo o da ditadura do proletariado. Isso significa, então, que todo Estado impõe o seu poder à sociedade por intermédio de um direito, e que, por essa mesma razão, o direito jamais pode ser o alicerce desse poder. Esse alicerce real só pode ser uma relação de forças históricas, alargadas ao conjunto das esferas de ação e de intervenção do Estado, isto é, ao conjunto das esferas de ação e de intervenção do Estado, ou seja ainda, do conjunto da vida social, uma vez que não há nenhuma esfera 
da vida social (principalmente o mundo "privado") imune à intervenção do Estado; isso porque a esfera de ação do Estado é por definição universal.

A teoria marxista do Estado de fato está situada na corrente realista do pensamento político, pois define o conflito de classes como motor da história, e o Estado tem um papel central na manutenção da ordem pelo meio da coação física. Mas, como chama atenção Balibar:

Não se trata de dizer que o Estado só age pela violência, mas de dizer que o Estado assenta numa relação de forças entre as classes, e não no interesse público e na vontade geral. Esta relação é inteiramente 'violenta' no sentido de que não é efetivamente limitada por nenhuma lei e uma legislação, uma legalidade, que, longe de por em causa essa relação violenta, não fazem mais do que sancioná-la (Balibar, 1977, p. 52).

A intervenção de Poulantzas nesse debate alinhava-se nitidamente à posição da esquerda eurocomunista. De forma alguma a sua defesa do socialismo democrático identificava-se com a vertente eurocomunista de Berlinguer e Carrillo, e tampouco com a social-democracia. A ruptura de Poulantzas com o leninismo não o afastou da "posição comunista", restringindo-se ao momento socialista. Com o seu distanciamento da perspectiva leninista, i.e., a ênfase no papel do partido de vanguarda na construção e na condução do processo revolucionário durante a fase de transição, Poulantzas abarcou as posições de Rosa Luxemburgo na crítica desta às primeiras medidas da Revolução Russa, como também na ação das massas, vide o destaque que ele deu aos novos movimentos sociais (feministas, ecológicos, estudantis, qualidade de vida, comitês de bairro, cidadania ${ }^{11}$ ) que emergiram durante os anos 1970.

Essa inclinação de Poulantzas ao luxemburguismo e à crítica ao leninismo foi expressa principalmente no livro $O$ Estado, o poder e o socialismo (particularmente na parte "Em direção a um socialismo democrático", também publicado em artigo pela New Left Review), de 1978, e nas entrevistas dadas às revistas Critique Communiste (intitulada "O Estado e a transição ao socialismo", com Henri Weber, em 1977), Dialectiques (denominada "O Estado, o poder e nós", dada a David Kaisergruber em 1977) Marxism Today (cedida a Stuart Hall e Alan Hunt em 1979), Rinascita ( "Uma revolução copernicana na política”, em 1979) e Dialectiques ( "O Estado, os movimentos sociais, o

11 Vide Poulantzas (2008, p. 411, e 1983b, p. 79). 
partido", em 1979) e nos artigos “Há uma crise no marxismo?", de 1979, e "Notas para uma pesquisa sobre o Estado e a sociedade", publicado em 1980.

A despeito das divergências entre Althusser e Poulantzas, havia algumas convergências entre ambos os pensadores no tocante à critica ao partido político revolucionário e sua tendência à burocratização e a sua fusão com o Estado (cf. Cavazzini, 2009, p. 86), e na defesa do papel das massas. No entanto, diferenciam-se pelo fato de que, enquanto Althusser enfatizava as lutas externas aos aparatos estatais, Poulantzas defendia a tese da internalização dessas lutas sociais nos aparelhos de Estado. Além disso, se para Althusser a ditadura do proletariado é um conceito central e estratégico na teoria marxista, e significa o próprio socialismo, i.e., a transição para o comunismo, Poulantzas, por sua vez, considera que, devido ao desenvolvimento teórico e histórico do marxismo, e da sua criatividade epistemológica, há transformações e criações, ou abandonos, de determinados conceitos, como a ditadura do proletariado, como ele afirma no artigo "Há uma crise no marxismo?" (cf. Poulantzas, 2008, p. 382) ${ }^{12}$.

A adoção da estratégia do chamado socialismo democrático, com efeito, expressava as mudanças no significado do conceito de Estado capitalista que Poulantzas já vinha implementando desde o livro As classes sociais no capitalismo de hoje, e que alcançou o seu grau de maturidade nos livros $A$ crise do Estado e $O$ Estado, o poder, o socialismo ${ }^{13}$. Se o Estado capitalista inicialmente fora definido em Poder político e classes sociais como uma instância, ou nível, do modo de produção capitalista (Poulantzas, 1977), aos poucos Poulantzas lhe deu um novo significado, ao defini-lo de modo relacional. Isso significa dizer - como ele bem demarca em seu debate com Henri Weber -que o Estado não é um sujeito autônomo (de acordo com a perspectiva social-democrata), tampouco um instrumento de classe (segundo a concepção mais vulgar do marxismo-leninismo), no qual seria homogêneo e impermeável às contradições sociais (Poulantzas, 2008, p. 334-335).

\footnotetext{
2 Em O Estado, o poder e o socialismo, Poulantzas também afirma que "a ditadura do proletariado foi em Marx uma noção estratégica em estado prático, funcionando ademais como painel indicador. Ela reconduzia à natureza de classe do Estado, à necessidade de sua transformação em face da transição para o socialismo e ao processo de desaparecimento do Estado. Se isso a que ela reconduz permanece real, esta noção teve, conseqüentemente, uma função histórica precisa: a de ocultar o problema fundamental, exatamente o da articulação de uma democracia representativa transformada e da democracia direta na base. Essas são verdadeiras razões que justificam, ao meu ver, seu abandono e não porque esta noção acabe por identificar-se com o totalitarismo stalinista" (Poulantzas, 1978, p. 283).

13 Sobre as mudanças operadas por Poulantzas na sua teoria sobre o Estado capitalista, ver Carnoy (1994), Motta (2010) e Codato e Perissinotto (2011).
} 
O Estado capitalista, na acepção relacional de Poulantzas, é permeado por fissuras e contradições, atravessadas pelas lutas de classes; além disso, a ossatura material do Estado capitalista é constituída pela divisão social do trabalho - o que significa dizer que as relações de produção estão presentes no Estado, e são reproduzidas por este. O Estado capitalista é, portanto, uma condensação material de relações de forças, pois ele mesmo é uma arena de lutas, de conflitos entre as classes e os grupos sociais, haja vista que nem todas as relações de poder e de conflito são redutíveis às classes sociais, ou à contradição entre as relações de produção e as forças produtivas. Desse modo, o Estado capitalista tem dentro de si uma multidão de micropolíticas em todos os aparatos existentes, embora estes estejam sobredeterminados pela macropolítica da divisão social do trabalho, i.e., da luta de classes. Os agentes de Estado, mesmo os dos aparatos repressivos, não estariam imunes a esses conflitos, ainda que estejam limitados pela ideologia dominante tal como ela se corporifica na ossatura do Estado. Isso significa afirmar que, mesmo que esses agentes absorvam as lutas populares, atuam dentro da legalidade possível para as suas ações.

A questão das relações de produção no interior dos aparelhos estatais, e de o Estado capitalista ser atravessado pelas lutas sociais é uma das questões que opõem Althusser a Poulantzas. Embora não cite em nenhum momento Poulantzas em seu texto "Marx dentro dos seus limites", Althusser dirige as suas críticas a ele ${ }^{14}$ ao defender a tese de que o Estado é separado das lutas de classes por se tratar de um instrumento de dominação burguesa, de acordo com os preceitos extraídos de Marx, Lênin e Mao. Como ele afirma, "se os grandes aparelhos estatais estiverem à mercê do atravessamento da luta de classe burguesa no Estado, isso poderia ser o fim da dominação burguesa" (Althusser, 1994, p. 438).

Em outra passagem crítica a Poulantzas, Althusser afirma: "Assim, defender que o Estado é 'por definição atravessado pela luta de classes', é tomar os seus desejos pela realidade. É tomar os efeitos, mesmo profundos, ou os traços da luta de classes (burguesa e proletária) pela própria luta de classes"

${ }^{14}$ Embora o artigo de L Felipe Alarcón (2010) enfoque a questão do conceito de Estado e não trate da estratégia de esquerda via ditadura do proletariado ou socialismo democrático, o título de seu trabalho é uma feliz ilustração dessa querela entre os dois intelectuais:"Cuestión de armas: en torno al diferendo Althusser - Poulantzas"(Questão de armas: sobre a disputa Althusser-Poulantzas). O confronto político entre ambos se dá pelas armas teóricas na definição do conceito de Estado e a estratégia propícia para a transição para o comunismo. 
(Althusser, 1994, p. 448). Mais adiante, na página 484, Althusser distingue as lutas corporativas e de descontentamento salarial dos agentes repressivos do Estado (magistratura, policiais) - que seriam greves motivadas pelas lutas pequenos burguesas - das lutas (greves) determinadas pelas contradições de classe que teriam um teor revolucionário. Paradoxalmente, Althusser vai de encontro à sua posição pretérita exposta em seu artigo "Nota sobre os AIE" (1999), quando reconhecia a existência da luta de classes e de resistência nos aparelhos de Estado. Como o próprio Althusser destaca:

Pode-se dizer que o caráter próprio da teoria que é possível retirar de Marx sobre a ideologia é a afirmação do primado da luta de classes sobre as funções e o funcionamento do aparelho de Estado, dos aparelhos ideológicos de Estado. Primado que é, evidentemente, incompatível com qualquer forma de funcionamento. (...) os aparelhos ideológicos de Estado são necessariamente o lugar e o objeto de uma luta de classes que, nos aparelhos da ideologia dominante, prolonga a luta de classes geral que domina a formação social. Se ao AIE têm a função de inculcar a ideologia dominante é porque há resistência; se há resistência é porque há luta; e essa luta é, no final das contas, o eco direto ou indireto, por vezes, próximo ou, frequentemente longínquo da luta de classes (Althusser, 1999, p. 239-241).

Retornando a Poulantzas, sua posição é clara quando se fundamenta em Rosa Luxemburgo em oposição a Lênin, pelo fato de ela ter defendido a manutenção da democracia representativa articulada à democracia direta, e não, como fez Lênin, apoiar-se exclusivamente nesta. Para Poulantzas, a questão é:

como compreender uma transformação radical do estado articulando a ampliação e o aprofundamento das instituições da democracia representativa e das liberdades (que foram também uma conquista das massas populares) com o desenvolvimento das formas de democracia direta na base e a proliferação de focos autogestores, esse é o problema essencial de uma via democrática para o socialismo e de um socialismo democrático (Poulantzas, 1978, p.283).

Conforme Poulantzas percebe e afirma no seu debate com Henri Weber, não é a estratégia de duplo poder que tem de ser constituída, i.e., a tomada do poder de Estado pelo assalto externo, mas sim a articulação da luta interna no Estado com a externa a ele. Essa estratégia articulada se caracteriza por uma luta interna ao Estado que não seja uma luta fechada no interior do espaço 
físico do Estado, mas uma luta que se situe de qualquer modo no terreno do campo estratégico representado pelo Estado, luta essa que não tem por finalidade substituir o Estado burguês pelo Estado proletário por acumulação de reformas nem tomar um a um os aparelhos do Estado burguês e conquistar, assim, o poder, mas uma luta que é de resistência, uma luta de acentuação das contradições internas do Estado, de transformação profunda do Estado. Ao mesmo tempo, uma luta paralela, uma luta no exterior das instituições e dos aparelhos, gerando uma série de dispositivos, redes, poderes paralelos na base, estruturas de democracia direta na base, luta que não teria por objetivo a centralização de um contra-Estado do tipo duplo poder, mas que deveria articular-se à primeira (cf. Poulantzas 2008, p. 338).

A divergência de Poulantzas com Althusser deve-se à posição política e à definição sobre o Estado capitalista deste último, mas não às suas posições filosóficas e metodológicas contidas em seus primeiros escritos, segundo o seu depoimento dado a Stuart Hall e Alan Hunt na revista Marxism Today. No campo teórico/metodológico a oposição de Poulantzas era dirigida ao estruturalismo de Balibar, cujas divergências ele demarcou desde Poder político e classes sociais, e continuou em outras obras como As classes sociais no capitalismo de hoje e $O$ Estado, o poder e o socialismo. De fato, a aproximação de Poulantzas à corrente esquerdista do eurocomunismo o levou a divergir explicitamente de Althusser ${ }^{15}$. Para Poulantzas a corrente direitista do eurocomunismo de Elleinstein (defendida por Marchais) seguia explicitamente a proposta de Kaustsky de uma revolução progressiva, gradual, pacífica, legal. Já a tendência esquerdista defendia uma democracia de massas, a qual incorpora tipos de ruptura e tipos de transformação ao próprio Estado. Daí não haver uma "quebra do Estado", não obstante a esquerda eurocomunista estivesse consciente do problema da necessidade de uma radical transformação, não somente dos aparelhos ideológicos de Estado mas também nos aparelhos

\footnotetext{
Em sua última entrevista, Poulantzas comenta suas convergências e divergências com Althusser em relação ao Estado capitalista:"A proposição de Althusser é, em certa medida, correta. Em minhas últimas obras tentei mostrar que frente às posições iniciais de Althusser, o Estado não pode ser considerado como uma instância ou nível totalmente distinto, das relações de produção e reprodução - uma instância que teria autonomia natural através dos diversos modos de produção. O Estado está presente na própria constituição das relações de produção, e não somente em sua reprodução como sustentará Althusser em seu artigo'Ideologia e aparelhos ideológicos de Estado'. (...) Há que ter em conta a função econômica do Estado em sua materialidade específica, seu papel declarado de organizador político da burguesia, e enfim, todos os seus procedimentos e técnicas de poder disciplinares e normalizadores" (Poulantzas, 1983b, p. 71).
} 
repressivos de Estado. A corrente de esquerda eurocomunista, segundo Poulantzas, retinha a insistência de um momento de ruptura no Estado. Não falavam de uma gradual e progressiva transformação do Estado. Eles tinham consciência de que haveria um momento decisivo e, embora não fosse em direção a uma guerra civil, seria um caminho de aprofundamento da crise do Estado, com uma mudança no balanço de forças dentro do próprio Estado (cf. Poulantzas, 2008, p. 389-391).

Apesar de sua aproximação com a esquerda eurocomunista, Poulantzas demarcou diferenças e críticas com Ingrao com relação à estratégia da revolução socialista. Ingrao, para Poulantzas, tem a posição inversa à de Althusser por enfatizar a luta no Estado, enquanto Althusser defendia a luta externa ao Estado:

Esta presença de redes estatais no "cotidiano" conduz, com efeito, ao que Ingrao chama de politização do social. Limites que perdem de vista, me parece, tanto Ingrao como Althusser. Ingrao, quando parece entender por politização uma possível "inclusão" exaustiva, inclusive desejável do social-privado, no Estado - "síntese" política. Althusser, quando critica Ingrao por esta visão da politização do social, ao considerá-la como politização burguesa (o político), ao mesmo tempo em que mantém a possibilidade de outra política, proletária desta vez, porém situada radicalmente "fora" do Estado (a política) em um não-lugar fantasmagórico. Parece-me, pois, que apesar das diferenças, Althusser e Ingrao adotam, de certo modo, uma mesma visão essencialista-topológica do Estado, o que leva a ambos, por diferentes caminhos (politização exaustiva do social) no Estado para Ingrao, politicamente proletária fora do Estado para Althusser), a um pan-politicismo generalizado (Poulantzas, 1983b, p. 73, grifos do original).

A quebra das instituições representativas é o ponto fulcral para Poulantzas durante o processo de transição. Apoiar-se exclusivamente na democracia direta não foi um impeditivo ao fortalecimento da burocracia estatal e partidária. Em seu rico debate com Henri Weber ele ressalta essa questão em diversas passagens (cf. Poulantzas, 2008, p. 344-345). Há a necessidade de manter a democracia representativa no período de transição, não obstante esse sistema representativo tenha de ser transformado e não seja uma mera reprodução do parlamentarismo burguês. Poulantzas enfatiza sempre a necessidade de articular a luta interna com a luta externa para que se crie uma situação de ruptura, já que a "ruptura revolucionária não se traduz obrigatoriamente na forma da centralização de uma contra-Estado face ao 
bloco do Estado" (Poulantzas, 2008, p. 340). “Quebrar” o Estado não significa nada para Poulantzas se não tiver como ponto central a transformação das relações de produção. A ruptura não se daria apena num momento e excluindo o Estado, já que a ruptura cruzaria o interior do Estado. De acordo com Poulantzas, a perspectiva de quebrar o Estado permanece válida como perspectiva de transformação profunda da estrutura do Estado.

A ruptura, de fato, não será exclusiva da ação dos partidos políticos. Poulantzas já no final dos anos 1970 já apontava o declínio deles no sistema representativo. Como ele observou, com a crise dos partidos políticos e do modelo do Welfare state houve a emergência e o crescimento dos novos movimentos sociais como novos conteúdos reivindicativos estranhos até então às representações tradicionais do campo da esquerda (cf. Poulantzas, 1983a, p. 39). Para ele os movimentos sociais que se produzem na base impulsionariam a proliferação de centros de democracia direta a partir das lutas populares que extravasam sempre o Estado. Para Poulantzas,

limitar-se ao terreno do Estado, por muito que se adote uma estratégia denominada de rupturista, equivale a deslizar-se insensivelmente para a social-democracia: em razão do próprio peso da materialidade do Estado a mudança da relação de forças no seu interior somente pode fazer-se apoiando-se também nas lutas e movimentos que extravasam o Estado (Poulantzas, 1983b, p.75).

Essa posição de Poulantzas está longe de se fixar na perspectiva reformista, haja vista que o objetivo da construção do que ele denomina de socialismo democrático tem com finalidade o fim do Estado. A transformação do aparelho de Estado no sentido do seu desaparecimento só pode apoiar-se numa intervenção ampla das massas populares no Estado, por meio de suas representações sindicais e políticas, mas também pelo desenvolvimento de suas iniciativas próprias dentro do Estado. Trata-se, como ele afirma:

de situar-se numa perspectiva global de desaparecimento do Estado, perspectiva que comporta dois processos: a transformação do Estado e o desenvolvimento da democracia direta na base. É a desarticulação desses dois movimentos que deu lugar a uma cisão sob a forma de duas tradições ${ }^{16}$, cisão de que se sabe o resultado (Poulantzas, 1978, p. 291).

${ }^{16}$ A social-democrata e a stalinista (LEM). 


\section{Conclusão}

Vimos neste artigo que o pensamento clássico marxista teve (e ainda tem) uma rica contribuição no tocante ao significado do conceito de Estado por este ser visto por esses pensadores como uma máquina repressora, ou como um conjunto de aparelhos de múltiplas práticas (ideológicas, políticas, repressoras e econômicas). Além disso, a questão sobre se há ou não oposição entre a democracia e a ditadura esteve presente desde o debate da II Internacional, e das divergentes posições pelos intelectuais e dirigentes marxistas dos anos 1970, o que veio a fornecer um rico material de reflexão e de pesquisa - contribuição teórica do marxismo constituída em oposição ao significado do conceito do Estado moderno e da democracia moderna numa clara oposição epistemológica ao universalismo presente na narrativa discursiva moderna.

A construção desses conceitos pelo marxismo é feita a partir da sua negação com uma afirmação alternativa no plano teórico-político. Como bem observa Negri, "é verdade que Marx não elaborou nenhuma teoria positiva do Estado e do direito. Isso não significa, porém, que uma análise marxista não tem nada a dizer sobre o Estado; significa, sim, que o ponto de partida para uma crítica marxista do Estado é expresso em termos negativos" (Negri e Hardt, 2004, p. 14) ${ }^{17}$. É a partir da negação e de uma outra afirmação que o marxismo trata do conceito do Estado e da democracia moderna: é a partir da ruptura, da descontinuidade e de uma resposta alternativa à problemática analisada e criticada.

O debate derradeiro dessa problemática foi travado entre Althusser e Poulantzas, dois personagens centrais dessa questão nos anos $1970^{18}$. Ao observarmos e analisarmos as propostas de transição de cada um, a maioria dos argumentos de ambos os pensadores são convergentes, pois a questão da

\footnotetext{
Em sua resposta direta a Bobbio em 1976 no artigo "Existe uma doutrina marxista do Estado?", Negri afirma precisamente que "o movimento operário revolucionário não conta com uma teoria do Estado porque - distintamente dos reformistas - não tem necessidade de prefigurações e/ou mistificações. O'quem'e'como' da transformação revolucionária compõem um só processo, por isso não faz muito sentido perguntar como vai ser eleito chefe da carrocinha na sociedade comunista e se seu mandato será revogável e imperativo. O problema dos clássicos consiste em definir as condições nas quais se desenvolve e deve - por necessidade -desenvolver-se o processo revolucionário" (Negri, 2003, p. 396-397).

${ }_{18}$ Além de Althusser e Poulantzas, estes representando o viés marxista e revolucionário, podem-se citar os nomes de Norberto Bobbio, expressando a tendência social-democrata, e, num nível um pouco mais abaixo, o de Claude Lefort simbolizando as correntes automistas herdeiras do anarquismo, não obstante compartilhasse com Bobbio vários preceitos do liberalismo político, entre eles a defesa do chamado "Estado de direito"em oposição ao "Estado totalitário" ("Estado autoritário", no caso de Bobbio).
} 
ruptura com o Estado capitalista e com o modelo democrático liberal está presente. A diferença se dá pela externalidade do Estado em relação às relações de produção por parte de Althusser (de que Poulantzas acertadamente discorda devido à presença da prática econômica nos aparatos estatais) e pela ênfase de Poulantzas no conceito de democracia (ou mais precisamente o de socialismo democrático) em detrimento do de ditadura do proletariado, pois este estaria historicamente "contaminado" com as práticas políticas autoritárias, particularmente pelas correntes leninistas, - e na sua expressão máxima - pelo stalinismo.

No entanto, passados mais de vinte anos desde o fim do socialismo europeu, e mais de trinta desde a crise do marxismo e do crescimento hegemônico do discurso democrático e/ou liberal no campo político e nas ideologias políticas, a conjuntura política se alterou sensivelmente nos últimos anos, desde a virada da última década. Em primeiro lugar, foi a democracia formal e institucionalista - e não a substantiva e a participativa - que se fortaleceu desde a crise do marxismo e do socialismo; em segundo, houve o malogro dos planos econômicos de reajuste fiscal e de cortes das áreas sociais transferidos para a política financeira (o significou um fortalecimento ainda maior das frações burguesas do capital financeiro), e com graves conseqüências sociais ampliando a taxa de desemprego, e aumentando a taxa da violência. Em terceiro, as agressões externas de caráter imperialista pelos EUA e a OTAN na Ásia e na África são construídas por meio de um discurso em defesa das instituições democráticas (e do mercado) para legitimar esse tipo de ação.

O fato é que tem havido desde o início deste século uma reação ao liberalismo, à democracia procedimental e às intervenções imperialistas, a exemplo da edificação de governos na América Latina de caráter desenvolvimentista, nacionalista, anti-imperialista, e que também lançaram novas formas de participação política, para além da democracia procedimental. Exemplo paradigmático disso são os governos da Venezuela e da Bolívia. Somam-se a isso a emergência de diversos movimentos sociais anti-neoliberais e movimentos de contestação política em várias formações sociais da Europa, além do retorno de organizações revolucionárias de caráter marxista. Não é casual que tenha havido desde a segunda metade dos anos 1990 a volta pelo interesse na teoria de Marx e dos marxistas.

Mas, quando Althusser e Poulantzas travaram o seu debate, a questão democrática (na defesa de seu aspecto "universal") estava a pleno vapor, e nos 
anos 1980 o liberalismo - agora acompanhado do prefixo "neo" - tornou-se dominante, afetando toda a Europa com as derrotas da social-democracia inglesa e escandinava, e influenciando diretamente as políticas econômicas dos partidos socialistas do mediterrâneo (espanhol, grego, português e francês, no segundo governo Mitterrand). Com a crise de várias formações socialistas acusadas de autoritarismo (ou "totalitarismo"), incluindo as não europeias como a China e o Camboja, que contaram com a simpatia de diversos marxistas althusserianos, Poulantzas abriu mão do conceito de ditadura do proletariado por considerá-lo insuficiente e optou pelo (não menos problemático) de "socialismo democrático". O problema que Poulantzas enfrenta nesse termo é que o denominado "socialismo democrático" possui várias acepções, como as de teor revolucionário, a exemplo dos luxemburguistas (na qual Poulantzas se identificava) ou de Ingrao, mas também a de socialistas reformistas-liberais como Bobbio, ou mesmo dos partidos social-democratas que reivindicavam a herança de Eduard Bernstein ${ }^{19}$.

A vantagem de Althusser (e de Balibar) é que a sua defesa do conceito de ditadura do proletariado de Marx é uma tomada de posição crítica à democracia-liberal, e a defesa de uma democracia de massas e da constituição de novas práticas políticas. O grande mérito do marxismo revolucionário em relação a esse conceito é a sua critica ao significado da democracia moderna (ou capitalista) já que ela não contém (tal qual a democracia antiga) uma prática (e não um "valor") universal. Ela é democrática para alguns segmentos da sociedade, mas não para a sua grande maioria. Isso é visível em termos de decisão que é confiada a uma minoria, ao corpo parlamentar que representa em sua grande maioria os interesses do grande capital e do conservadorismo (que conseguem bancar campanhas milionárias), e o monopólio da grande mídia (controlada praticamente por pequenos grupos que divulgam e distorcem os fatos noticiados). Não há democracia plena em termos reais, já que há a existência de práticas coativas, autoritárias sobre uma grande massa desinformada dos seus direito básicos. Ademais, as democracias capitalistas não mostraram tolerância a qualquer sinal de mudança em seu sistema, vide

\footnotetext{
${ }^{19}$ A dificuldade em diferenciar o socialismo democrático da social-democracia fica nítida nesse texto de um dos divulgadores do "socialismo democrático" no Brasil: "num sentido amplo, os partidos pertencentes à Internacional Socialista podem ser divididos em social-democratas e socialistas democráticos. Os primeiros aceitam o Estado do Bem-Estar (Welfare State) como o seu objetivo, enquanto os últimos vêem a social-democracia como um estágio na direção do estabelecimento do socialismo democrático" (Cavalcanti, 1979, p.118).
} 
as tentativas de desestabilização dos governos de Chávez, Morales e Correa pelo grande capital e pela mídia, tal qual como ocorreu contra Allende nos anos 1970. Nesse aspecto o termo "socialismo democrático" soa como uma concessão de Poulantzas à posição dos que defendem a democracia enquanto uma forma de regime político, ou mesmo enquanto um "valor universal".

João Quartim de Moraes, em seu artigo com o feliz título "Contra a canonização da democracia”, em que polemiza diretamente contra Carlos Nelson Coutinho, ele afirma:

De seu lado, o marxismo não recusa, em princípio, a idéia da transição do capitalismo ao socialismo pela via democrática. Sempre é bom lembrar que quem recusa essa via é a burguesia, como o atestam as dezenas de golpes de Estado que derrubaram governos de esquerda, no mais das vezes com atrozes banhos de sangue. Insiste, entretanto, no condicionamento da política pela economia, e, consequentemente, em que as formas do Estado se assentam na base econômica da sociedade. Portanto, sobre a base das relações capitalistas de produção, a democracia será sempre a forma política da dominação de classe da burguesia. Donde a necessidade objetiva de uma ruptura abrindo a via para a passagem da ordem do capital à ordem socialista (Moraes, 2001, p. 23).

Atílio Boron segue também a mesma posição ao afirmar a impossibilidade pacífica da instauração do socialismo pela via legal, ou pacífica, mediante a reação conservadora do capital em não ceder, ou transferir, o seu poder para os setores dominados que almejam romper com essas relações de poder por meio da criação de novas formas de práticas políticas:

Algumas almas cândidas acreditam que nos novos tempos democrático a direita e o imperialismo vão se abster de aplicar métodos violentos para frustrar o projeto transformador. Não mais 'pinochetismo', não mais paramilitares...Infelizmente, isso não é assim, e toda essa perspectiva - na verdade, uma simples esperança, mais que uma perspectiva - está baseada na aceitação de uma série de falsas premissas. Em primeiro lugar, existe a falsa noção de que as mudanças sociais e políticas podem ser realizadas sem despertar fortes resistências. Tal como dissemos em inúmeras ocasiões, as mais moderadas iniciativas reformistas promovidas pelas organizações em geral terminam num banho de sangue, principalmente no Terceiro Mundo. E, em segundo lugar, e ainda mais problemático: não existe nenhuma evidência histórica que demonstre que uma classe dominante, ou uma aliança de classes dominantes, tenha renunciado voluntariamente ao poder, às suas riquezas e aos seus privilégios após ter iniciado um processo radical de transformações sociais (Boron, 2011, p. 94). 
A defesa de Althusser do conceito de ditadura do proletariado corresponde mais ao atual contexto político do que a tomada de posição de Poulantzas em relação ao socialismo democrático. O mérito do marxismo na política é o de desnudar as práticas de poder que são reproduzidas em nome da democracia capitalista, e o conceito de ditadura do proletariado provoca isso ao rejeitar que haja uma democracia para todos no capitalismo devido à desigualdade socio-política-econômica reproduzida por seus aparatos. Essa é uma demarcação do pensamento marxista diante da democracia substancializada pelo liberalismo que se sustenta em preceitos e princípios abstratos que não condizem com o real. A igualdade apregoada pela democracia burguesa é um dos pontos máximos do imaginário: "vive-se" em algo inexistente, embora acredite-se categoricamente nessa "realidade". A atualidade do marxismo deve-se principalmente a seu arsenal teórico desconstrutivo e destruidor da modernidade burguesa, e pela sua proposta alternativa político-societal do comunismo que se apresenta como uma ruptura com o capitalismo e com a perspectiva centrada no indivíduo, e pelo estabelecimento do comum como eixo central na constituição das relações sociais. E, com nova crise de legitimidade que passa na atualidade o capitalismo, o pensamento marxista, e em particular a sua vertente althusseriana, tem uma grande contribuição a dar para os processos de ruptura que se avizinham, seja para desmascarar o imaginário democrático do capitalismo, seja para a análise da pluralidade contraditória, seja para a constituição de novas e diferentes estratégias nos diversos aparelhos de Estado.

\section{Referências}

ALARCÓN, L Felipe (2010). “Cuestión de armas: en torno al diferendo Althusser-Poulantzas”, em BÓRQUEZ, Zeto \& RODRÍGUEZ, Marcelo (orgs.). Louis Althusser: filiación y (re)comienzo. Santiago: Universidad de Chile.

ALTHUSSER, Louis (1978). O $22^{\circ}$ Congresso. Lisboa: Estampa.

(1994). Écrits philosophiques et politiques. Tome I. Paris: Stock, Imec. (1998). Solitude de Machiavel. Paris: PUF.

(1999) "Nota sobre os AIE (Aparelhos Ideológicos de Estado)", em Sobre a reprodução. Petrópolis: Vozes

BALIBAR, Étienne (1975). Cinco estudos sobre o materialismo histórico. 2 vols. Lisboa: Presença, Martins Fontes. 
(1977). Sobre o conceito de ditadura do proletariado. Lisboa: Moraes. BERLINGUER, Enrico (1977). Do compromisso histórico ao eurocomunismo. Lisboa: Antídoto.

(2009). Democracia, valor universal. Rio de Janeiro: Contraponto. BERNSTEIN, Eduard (1997). O socialismo evolucionário. Rio de Janeiro: Jorge Zahar, Instituto Teotônio Vilela.

BOBBIO, Norberto (1991). O marxismo e o Estado. Rio de Janeiro: Graal. BORON, Atílio (2011). Aristóteles em Macondo. Rio de Janeiro: Pão e Rosas. CARLINO, Fabrizio (2010). "Crise do marxismo e stalinismo. Notas sobre algumas posições de Louis Althusser - 1976-1978”. Germinal: Marxismo e Educação em Debate, v. 2, n. 2, p. 104-117.

CARNOY, Martin (1994). Estado e teoria política. São Paulo: Papirus.

CARRILLO, Santiago (1978). "Eurocomunismo" e Estado. Rio de Janeiro, São Paulo: Difel.

CAVALCANTI, Pedro Celso Uchoa (1979). "A Internacional Socialista vai à América Latina”. Encontros com a Civilização Brasileira, n. 9, p. 111-119. CAVAZZINI, Andrea (2009). Crise du marxisme et critique de l' Etat. Le dernier combat d'Althusser (suivi de l"Etat, le marxisme, le communisme: um débat entre Althusser et Poulantzas). Paris: Le Clou Dans le Fer.

CODATO, Adriano \& PERISSINOTO, Renato (2011). Marxismo como ciência social. Curitiba: UFPR.

INGRAO, Pietro (1980). As massas e o poder. Rio de Janeiro: Civilização Brasileira.

JESSOP, Bob (1985). Nicos Poulantzas: marxist theory and political strategy. New York: St. Martin's Press.

KAUTSKY, Karl \& LENIN, Vladimir Ilitch (1979). A ditadura do proletariado; A revolução proletária e o renegado Kautsky. São Paulo: Ciências Humanas LÊNIN, Vladimir Ilitch (1978). Obras escolhidas. 2 vols. Lisboa: Avante.

LUXEMBURGO, Rosa (2011). Textos escolhidos. 2 vols. Organização de Isabel Loureiro. São Paulo: Editora UNESP.

MARTORANO, Luciano Cavini (2011). Conselhos e democracia: em busca da participação e da socialização. São Paulo: Expressão Popular.

MORAES, João Quartim de (2001). "Contra a canonização da democracia”. Crítica Marxista, n. 12, p. 9-40. São Paulo: Boitempo.

MOTTA, Luiz Eduardo (2010). "Poulantzas e o direito". Dados, v. 53, n. 2, p. 367-403. 
NEGRI, Antonio (2003). La forma-Estado. Madri: Akal.

NEGRI, Antonio \& HARDT, Michael (2004). O trabalho de Dioniso: para a crítica ao Estado pós-moderno. Rio de Janeiro: Pazulin, Editora UFJF.

POULANTZAS, Nicos (1977). Poder Político e Classes Sociais. São Paulo: Martins Fontes.

(1978). L'État, le pouvoir et le socialisme. Paris: PUF.

(1983a). "Une révolution copernicienne dans la politique", em BUCI-GLUCKSMANN, Christinne (coord.). La, gauche, le pouvoir, le socialisme. Paris: PUF.

(1983b). “O Estado, os movimentos sociais, o Partido". Espaço e debates, n. 9, p. 70-79. São Paulo: Cortez.

(2008). The Poulantzas reader. Organização de James Martin. Nova York: Verso.

\section{Resumo}

A problemática da democracia não é estranha, nem alheia ao pensamento marxista. Contrariamente a isso, a democracia foi uma das principais questões debatidas no início do século XX pelo marxismo da II Internacional como também nos anos 1970 com a emergência do "eurocomunismo". Nesse último contexto o debate ficou marcado pelas intervenções de Louis Althusser e Nicos Poulantzas sobre o conceito de ditadura do proletariado e o de socialismo democrático, nas quais demarcavam ainda qual a estratégia que deveria ser adotada pelos partidos e movimentos de esquerda. O pano de fundo desse debate entre os pensadores estabeleceu uma rica análise sobre o significado do conceito de democracia no pensamento marxista, que demarca as suas diferenças em relação ao pensamento político moderno na sua definição de Estado e de democracia.

Palavras-chave: Althusser; Poulantzas; ditadura do proletariado; democracia.

\section{Abstract}

The issue of democracy is not strange or alien to Marxist thought. Contrary to this, democracy was one of the main issues discussed at the beginning of the twentieth century by the Marxism of the Second International as well as in the 1970s with the emergence of "Eurocommunism". In this latter context the debate was marked by speeches by Louis Althusser and Nicos Poulantzas on the concept of dictatorship of the proletariat and democratic socialism in which they demarcate what strategy should 
be adopted by Leftist parties and movements. The backdrop of that debate among thinkers established a rich analysis on the meaning of the concept of democracy in Marxist thought, which demarcates their differences in relation to modern political thought in its definition of state and democracy.

Keywords: Althusser; Poulantzas; dictatorship of the proletariat; democracy.

Recebido em 14 de agosto de 2013.

Aprovado em 5 de novembro de 2013. 